\title{
Postavení warfarinu v dnešni době: budeme jej ještě potřebovat? - editorial
}

\author{
Jan Kvasnička \\ Centrální hematologické laboratoře a Trombotické centrum Ústavu lékařské biochemie a laboratorní diagnostiky 1. LF UK a VFN \\ v Praze

\section{Komentář k | Editorial on} \\ Michalcová j et al. Postavení warfarinu v současné době. Vnitř Lék 2017; 63(12): 957-966.
}

Michalcová et al uvádějí v článku velmi sofistikovaný a instruktivní přehled o dosavadní antikoagulační léčbě warfarinem, který u nás patří $\mathrm{k}$ nejdéle používaným lékům v klinické medicíně. V současné době jej v České republice stále používá asi $66 \%$ perorálně antikoagulovaných nemocných. Většinou jsou léčeni u praktických všeobecných lékařů. Postupně však narůstá počet pacientů, kteří již užívají nová perorální antikoagulancia (NOAC), jako je dabigatran etexilát (10,4 \% pacientů), rivaroxaban (14,1\% pacientů) a apixaban (9,1 \% pacientů) [1]. Jedním z důvodů, proč narůstá počet pacientů léčených NOAC, je nutnost pečlivé kontroly antikoagulačního účinku warfarinu, která u NOAC není nutná. Léčbu warfarinem však kontrolovat musíme a jeho dávku v průběhu léčby pak měnit podle dosažených hodnot INR. Z praxe je však známo, že u dlouhodobě léčených pacientů je jen u 33-64\% dosahováno uspokojivých hodnot INR v terapeutickém rozmezí 2,03,0 . Většina z léčených je tímto prípravkem poddávkována (až v 39-75 \% s INR < 2,0), o asi 1/2 méně je předávkováno (INR > 3,5) [2]. Tím se pak snižuje efekt léčby, nebo se zvýší riziko krvácení. Je to vidět zejména v poslední době, v níž spolu s nárůstem preskripce warfarinu u nemocných s nevalvulární fibrilací síní dochází i k nárůstu krvácení [3].

Dnes již víme, že mimo problémů spjatých s dodržováním laboratorní kontroly, nedostatečné spolupráce pacientů a dalších rizik, zvyšujících tendenci k poddávkování nebo předávkování léčby warfarinem, je farmakokinetický i farmakodynamický účinek warfarinu u léčené osoby podmíněn zejména geneticky. Warfarin je velmi účinným antagonistu vitaminu $\mathrm{K}_{1}$, který je nezbytný pro syntézu funkčních koagulačních faktorů II, VII, IX a X v játrech. Tento vitamin je totiž potřebný pro aktivaci enzymu $\gamma$-karboxylázy v jaterní buňce, která pak umožní tzv. $\gamma$-karboxylaci syntetizovaných koagulačních faktorů. Teprve potom jsou koagulačně účinné, tj. mohou se vázat pomocí $\mathrm{Ca}^{2+}$ můstků s fosfolipidy membrány destiček, či s tkáňovým faktorem a mezi sebou. Vitamin $\mathrm{K}_{1}$ se však v lidském organizmu nesyntetizuje, získává se z potravy. Lidský organizmus si proto aktivní, redukovanou formu vitaminu $\mathrm{K}$ (vitamin $\mathrm{K}$ hydrochinonon, $\mathrm{KH}_{2}$ ) stále obnovuje $\mathrm{z}$ jeho

\begin{tabular}{|c|c|c|c|c|c|}
\hline \multirow[t]{2}{*}{ senzitivita warfarinu } & \multicolumn{2}{|c|}{ kombinace genotypu } & \multirow{2}{*}{$\begin{array}{l}\text { prevalence v ČR } \\
\quad(n=1448)\end{array}$} & \multirow[t]{2}{*}{ klinické doporučení } & \multirow{2}{*}{$\begin{array}{l}\text { průměrná denni } \\
\text { dávka warfarinu } \\
(\mathrm{mg})\end{array}$} \\
\hline & VKORC 1 & СYP2C9 & & & \\
\hline \multirow{2}{*}{ velmi vysoká } & $\mathrm{A} / \mathrm{A}$ & ${ }^{*} 1 /{ }^{*} 3, * 2 / * 2, * 2 /{ }^{*} 3 /{ }^{*} 3$ & \multirow{2}{*}{$1,7 \%$} & \multirow{2}{*}{$\begin{array}{l}\text { snižizit dávku } \\
\text { + častěji INR }\end{array}$} & \multirow{2}{*}{$<2,0-2,1$} \\
\hline & $\mathrm{G} / \mathrm{A}$ & $* 3 / * 3$ & & & \\
\hline \multirow{3}{*}{ vysoká } & $\mathrm{A} / \mathrm{A}$ & $* 1 / * 2$ & \multirow{3}{*}{$3,0 \%$} & \multirow{3}{*}{$\begin{array}{l}\text { snížit dávku } \\
\text { + častěji INR }\end{array}$} & \multirow{3}{*}{$2,6-3,5$} \\
\hline & $\mathrm{G} / \mathrm{A}$ & $* 2 / * 3$ & & & \\
\hline & G/G & $* 3 / * 3$ & & & \\
\hline \multirow{3}{*}{ střední } & $\mathrm{A} / \mathrm{A}$ & $* 1 / *_{1}$ & & \multirow{3}{*}{$\begin{array}{l}\text { snižit dávku } \\
\text { + častěji INR }\end{array}$} & \multirow{3}{*}{$3,5-4,1$} \\
\hline & $\mathrm{G} / \mathrm{A}$ & ${ }^{*} 1 /{ }^{*} 2,{ }^{*} 1 /{ }^{*} 3,{ }^{*} 2 /{ }^{*} 2$ & $25,8 \%$ & & \\
\hline & G/G & $* 2 / * 3$ & & & \\
\hline mírná & $\mathrm{G} / \mathrm{G}$ & ${ }^{*} 1 /{ }^{*} 2, * 1 /{ }^{*} 3,{ }^{*} 2 /{ }^{*} 2$ & $13,0 \%$ & častěji kontrola INR & 5,3 \\
\hline normální & $\mathrm{G} / \mathrm{A}$ & ${ }^{*} 1 /{ }^{* 1}$ & $27,7 \%$ & běžná léčba dle SPC & 5,6 \\
\hline méně než normální & $\mathrm{G} / \mathrm{G}$ & ${ }^{*} 1 /{ }^{*} 1$ & $28,8 \%$ & $\begin{array}{l}\text { snižit dávku } \\
\text { + častěji INR }\end{array}$ & $6,1>7,0$ \\
\hline
\end{tabular}


oxidované formy (vitamin K 2,3-epoxid, KO) pomocí enzymu vitamin K-epoxidreduktázy, respektive komplexu izoforem tohoto enzymu, který se nazývá komplex reduktázy vitaminu K, podjednotka 1 (zkratka VKORC1). VKORC1 je pak warfarinem inhibován a recyklace redukované formy vitaminu $\mathrm{K}_{1}$ a následná $\mathrm{\gamma}$-karboxylaxe koagulačních faktorů je snížena. To pak vede k antikoagulačnímu účinku warfarinu. $\mathrm{V}$ genu VKORC1 však dochází poměrně často $\mathrm{k}$ mutaci $\mathrm{v}$ jeho promotorové oblasti spojené $\mathrm{s}$ konverzí guaninu za adenin $\mathrm{v}$ pozici -1639 (-1639 G > A, rs 9923231), která vede k snížené translaci mRNA a nižší tvorbě enzymu VKORC1. Výskyt této mutace tedy u svého nositele zvyšuje senzitivitu na warfarin. Další geneticky podmíněný účinek warfarinu spočívá $v$ tom, že jeho biotransformace, aktivita a doba, po kterou působí v organizmu, závisí i na aktivitě různých forem cytochromů systému $\mathrm{P} 450 \mathrm{v}$ jaterních buňkách, především cytochromu P 450 2C9. Ten je odpovědný za konverzi farmakologicky více účinného S enantiomeru warfarinu na jeho neaktivní metabolity. Pacientům s alelami 2C9*2 (mutace genu CYP 2C9 se záměnou cytosinu C v pozici 430 za tymidin T, 430 C > T, rs 1799853) a 2C9*3 (mutace genu CYP 2C9 se záměnou adeninu $A$ za cytosin C v pozici 1075,1075 A > C, rs 1057910) pak k udržování optima INR stačí menší dávky warfarinu než pacientům s nemutovanou alelou 2C9*1. Je to o $17 \%$, resp. o $37 \%$ méně. V České republice se prevalence osob s geneticky danou vyšší senzitivitou na warfarin pohybuje kolem 30 \% [4]. U asi $3 \%$ osob s výskytem homozygotních forem obou mutací pak hrozí krvácení již při zahájení léčby warfarinem, kdy je v úvodu podáván spolu s hepariny. Prevalenci výskytu i vlivu na dávkování a kontrolu INR uvádíme v tab.

Přes tyto nedostatky má však warfarin proti NOAC jednu výhodu: při pečlivém monitorování jeho účinku můžeme individualizovaným dávkováním ovlivňovat intenzitu jeho antikoagulačního účinku. To je nutné např. při prevenci kardioembolických příhod u nemocných s náhradou srdečních chlopní, zejména mechanických, u nichž je třeba podle výše rizika tromboembolie (trombotická příhoda v anamnéze, náhrada trikuspidální nebo mitrální chlopně, fibrilace síní, mitrální stenóza nebo ejekční frakce levé komory < 35 \%) nemocné dlouhodobě léčit warfarinem a dodržovat přitom INR až 4,0 [5]. Usilujeme proto (Česká kardiologická společnost a Česká společnost pro trombózu a hemostázu České lékařské společnosti J. E. Purkyně), aby zdravotní pojištovny hradily pro tyto nemocné možnost sebekontroly INR přenosnými prístroji, jako je např. CoaguChek ${ }^{\circledR}$ aj, s cílem snížit během potřebné dlouholeté léčby výskyt poddávkování, nebo předávkování warfarinem.

\section{Podpořeno institucionální podporou výzkumu RVO VFN} 64165.

\section{Literatura}

1. IMS Dataview - software společnosti Quintiles IMS. Dostupné z WWW: <http://www.quintiles.com>.

2. Guyatt $\mathrm{GH}, \mathrm{Akl}$ EA, Crowther $M$ et al. Antithrombotic Therapy and Prevention of Thrombosis, 9th ed. American College of Chest Physicians Evidence-Based Clinical Practice Guidelines. Chest 2012; 141(2 Suppl): 7S-47S. Dostupné z DOI: <http://dx.doi.org/10.1378/ chest.1412S3>. Erratum in Chest 2012; 141(4): 1129. Dosage error in article text. Chest 2012; 142(6): 1698. Dosage error in article text.

3. Čihák R, Heinc P, Haman L et al. Fibrilace síní. Doporučený diagnostický a léčebný postup České kardiologické společnosti vypracovaný Pracovní skupinou arytmie a trvalé kardiostimulace. Cor Vasa 2011; 53(Suppl 1): 27-52.

4. Kvasnička J, Hájková J, Bobčíková P et al. Prevalence polymorfismů CYP2C9 a VKORC1 v České republice a zamyšlení nad výhledy antikoagulační léčby warfarinem. Cor Vasa 2011; 53(10): 522-526.

5. Baumgartner H, Falk V, Bax JJ et al. 2017 ESC/EACTS Guidelines for the management of valvular heart disease. Eur Heart J 2017; 38(36): 2739-2791. Dostupné z DOI: <http://dx.doi.org/10.1093/eurheartj/ ehx391>.

prof. MUDr. Jan Kvasnička, DrSc. \jan.kvasnicka@vfn.cz

Centrální hematologické laboratoře a Trombotické centrum Ústavu lékařské biochemie a laboratorní diagnostiky 1. LF UK a VFN v Praze

www.vfn.cz

Doručeno do redakce 26. 9. 2017 